\title{
New information on the geochemistry of Neoarchean Sanukitoids from Eastern Dharwar Craton, Southern India; implications to regional tectonics.
}

\author{
NAMRATA KHADKE ${ }^{1,2}$, VIJAYA KUMAR TEEDA ${ }^{1,2}$, \\ BHASKAR RAO YERRAGUNTLA ${ }^{2}$ AND E.V.S.S.K. \\ BABU $^{1,2}$ \\ ${ }^{1}$ Academy of Scientific \& Innovative Research (AcSIR) \\ ${ }^{2}$ CSIR-National Geophysical Research Institute \\ Presenting Author: namrata.ck90@gmail.com
}

The Eastern Dharwar Craton (EDC) is considered to have accreted during the late Neoarchean $(2.7-2.5 \mathrm{Ga})$. The craton comprises a series of arcuate NNW-SSE greenstone belts separated by plutons of high-K granites, (locally with sanukitoid affinities) and migmatite gneiss. The EDC has also been perceived as a Neoarchean ultra-hot orogen accreted to an older craton the Western Dharwar craton. Sanukitoids are high-Mg granitoids with geochemical characters similar to certain high$\mathrm{Mg}$ andesites in Phanerozoic convergent margin settings as well as intermediate components of Archean tonalite-trondhjemitegranodiorite (TTG). They are enriched in both compatible (eg., $\mathrm{Mg}, \mathrm{Ni}$ and $\mathrm{Cr}$ ) and incompatible (eg., $\mathrm{Ba}, \mathrm{Sr}, \mathrm{K}$ and LREE) elements. Their genesis is ascribed to a two-stage process: enrichment of mantle wedge peridotite by fluids, melts or sediments from a subducting oceanic slab followed by partial melting of the metasomatised wedge in a thermal event at the terminal stage of subduction. Their transitional characters are not only compositional but also chronological, as they become increasingly abundant around the Archean-Proterozoic boundary which is marked by a geodynamic transition towards a plate tectonics and Wilson-cycle processes.

Examples of low-Ti sanukitoids from the EDC have been documented in previous studies[1][2] that proposed a genetic model involving melting of a metasomatised peridotite mantle wedge. Here we report new geochemical data on sanukitoids from the eastern and northeastern margins of the EDC. Our samples are drawn from around Peechera-Mallaram villages, of Telangana State. Notably, some of our samples show higher $\mathrm{TiO}_{2}$ than those described earlier[2]. We interpret their geochemistry in terms of a mantle source in the stability field of garnet $(>45$ $\mathrm{km}$ depth) in a Neoarchean subduction setting.

[1] H. Martin, J. F. Moyen, and R. Rapp, "The sanukitoid series : Magmatism at the Archaean-Proterozoic transition The sanukitoid series : magmatism at the Archaean - Proterozoic transition," vol. 100, no. December 2013, pp. 15-33, 2010.

[2] O. Laurent, R. Doucelance, H. Martin, and J. F. Moyen, "Differentiation of the late-Archaean sanukitoid series and some implications for crustal growth: Insights from geochemical modelling on the Bulai pluton, Central Limpopo Belt, South Africa," Precambrian Res., vol. 227, pp. 186-203, 2013. 